\title{
Studi Eksperimental Beton Mutu Tinggi Dengan Agregat Batok Kelapa Dan Terak Baja
}

\author{
Anisa Tikupadang**1, Herman Parung*², Benny Kusuma*3 \\ *I Mahasiswa Program Studi Teknik Sipil, Universitas Kristen Indonesia. Paulus, Makassar, \\ Indonesia, anishatikupadang@gmail.com \\ ${ }^{* 2 * 3}$ Dosen Program Studi Teknik Sipil, Universitas Kristen Indonesia Paulus, Makassar, Indonesia \\ hermanparung@gmail.com dankusumab06@yahoo.com
}

Correspondent Author: anishatikupadang@gmail.com

\begin{abstract}
Abstrak
Terak baja merupakan limbah buangan dari industri peleburan baja. Seiring dengan kebutuhan baja yang semakin meningkat, dapat pula menyebabkan limbah baja semakin meningkat. Batok kelapa merupakan limbah yang bersifat padat dari sisa pengolahan kelapa. Dalam penelitian ini bertujuan mendapatkan kuat tekan, kuat tarik belah, kuat lentur, dan modulus elastisitas dengan agregat kasar substitusi terak baja dan batok kelapa, dengan mutu beton yaitu f'c $45 \mathrm{MPa}$. Hasil dari penelitian ini kuat tekan beton yang diperoleh, agregat batu pecah 100\% mengalami kenaikan 5,213\% dan subsitusi batok kelapa dan terak baja mengalami kenaikan 1,650\%. Nilai kuat tarik belah beton, batu pecah $100 \%$ sebesar $9,312 \%$ dan substitusi batok kelapa dan terak baja sebesar 9,073 dari kuat tekan. Nilai kuat lentur, batu pecah $100 \%$ sebesar $0,827 \sqrt{ }\left(\mathrm{f}^{\prime} \mathrm{c}\right)$ dan substitusi batok kelapa dan terak baja sebesar 0,752 f'c dari kuat tekan. Nilai Modulus elastisitas beton, batu pecah $100 \%$ sebesar 24845,351 MPa dan substitusi batok kelapa dan terak baja sebesar 20674,005 MPa.
\end{abstract}

Kata Kunci: kuat tekan, kuat tarik belah, kuat lentur, modulus elastisitas, terak baja, batok kelapa

\begin{abstract}
Steel slag is a waste from the steel smelting industry. Along with the increasing demand for steel, it can also cause steel waste to increase. Coconut shell is a solid waste from the rest of coconut processing. This study aims to obtain the compressive strength, split tensile strength, flexural strength, and modulus of elasticity with coarse aggregate substituted for steel slag and coconut shell, with a concrete quality of $f^{\prime} c 45 \mathrm{MPa}$. The results of this study that the compressive strength of concrete obtained, $100 \%$ crushed stone aggregate increased $5.213 \%$ and coconut shell substitution and steel slag increased $1.650 \%$. The value of the split tensile strength of concrete, $100 \%$ crushed stone is $9.312 \%$ and the substitution of coconut shells and steel slag is 9.073 of the compressive strength. The value of flexural strength, $100 \%$ crushed stone is $0.827 \sqrt{ }\left(f^{\prime} c\right)$ and the substitution of coconut shell and steel slag is $0.752 f^{\prime} \mathrm{c}$ from the compressive strength. The modulus of elasticity of concrete, $100 \%$ crushed stone is $24845,351 \mathrm{MPa}$ and substitution of coconut shells and steel slag is 20674,005 MPa.
\end{abstract}

Keywords: compressive strength, split tensile strength, flexural strength, modulus of elasticity, steel slag, coconut shell 


\section{PENDAHULUAN}

Beton merupakan bahan konstruksi yang penting pada struktur bangunan dengan bahan penyusun agregat kasar, agregat halus, air, dan semen. Dalam pembuatannya beton dapat dibentuk sesuai dengan kebutuhan, perawatan yang murah, dapat menggunakan bahan-bahan lokal, dan mempunyai kuat tekan yang tinggi. Beton mutu tinggi adalah beton yang mempunyai kuat tekan di atas beton normal. Terak baja merupakan limbah buangan dari industri peleburan baja. Seiring dengan kebutuhan baja yang semakin meningkat, dapat pula menyebabkan limbah baja semakin meningkat. Batok kelapa merupakan limbah yang bersifat padat dari sisa pengolahan kelapa. Jumlah ketersediaan batok kelapa yang ada di Indonesia cukup melimpah. Sehingga perlu dilakukan penanganan agar limbah yang ada dapat dimanfaatkan kembali, dapat menjadi nilai tambah secara ekonomi dan mengurangi dampak pencemaran lingkungan. Terak baja dan batok kelapa memiliki sifat fisik yang padat dan keras. Dari sifat tersebut ingin diketahui kekuatan beton menggunakan terak baja dan batok kelapa sebagai substitusi agregat kasar dalam campuran beton.

Tujuan dari penelitian ini yaitu untuk mengetahui nilai kuat tekan, kuat tarik belah, kuat lentur, dan modulus elastisitas beton dengan mutu f'c $45 \mathrm{MPa}$ dengan substitusi agregat kasar batok kelapa dan terak baja dalam campuran beton mutu tinggi dan mengetahui perbandingannya dengan beton yang menggunakan agregat batu pecah $100 \%$.

Beberapa penelitian sejenis dengan hasilnya, yaitu pengaruh terak baja sebagai pengganti sebagian agregat kasar dan variasi umur beton berpengaruh terhadap kuat tekan beton [1], Bahwa nilai slump yang di dapatkan untuk beton normal dengan nilai $8 \mathrm{~cm}$, beton campuran limbah asbes $20 \%$ dengan nilai $6 \mathrm{~cm}$, dan untuk campuran limbah terak baja $50 \%$ dengan nilai $10 \mathrm{~cm}$ [2], Karakteristik beton campuran tempurung kelapa berdasarkan hasil kuat tekan beton K-100 pada umur 7 hari perawatan dapat meningkat dengan penambahan 5\% tempurung kelapa yaitu sebesar 16,5 Ton atau 73,33 $\mathrm{Kg} / \mathrm{Cm}^{2}$ dengan proyeksi kekuatan pada umur 28 hari sebesar $112,82 \mathrm{Kg} / \mathrm{Cm}^{2}$ [3], pada beton varian mengalami penuruan kuat tekannya, semakin banyak campuran maka semakin menurun pula kuat tekannya [4], penggunaan terak baja sebagai bahan pengganti sebagian semen terhadap kuat tekan beton mutu tinggi [5], Penggantian terak dan variasi umur berpengaruh terhadap kuat tekan beton terak baja [6], penggantian sebagian agregat halus dengan terak besi berpengaruh terhadap kuat tekan paving block [7], Pengaruh Polypropylene Fiber pada matriks beton mutu tinggi yang menggunakan slag baja sebagai agregat kasar dapat meningkatkan sifat mekanis beton [8], Pemakaian beton terak nikel dapat digunakan untuk bangunan dan agar massa bangunan tidak terlalu berat, maka campuran beton sebaiknya menggunakan agregat terak nikel yang berpori, karena berat jenis yang lebih ringan daripada agregat terak nikel padat [9], Pada beton variasi 3\% tempurung kelapa $+20 \%$ fly ash hasil kuat tekan beton sebesar 23,27 Mpa dan menunjukan penurunan sekitar 22,61\% dari beton normal yang hasil kuat tekan beton sebesar 30,07 Mpa. variasi beton $4 \%$ tempurung kelapa $+20 \%$ fly ash hasil kuat tekan beton sebesar 23,36 Mpa dan mengalami penurunan 22,31\% dari beton normal [10].

\section{METODE PENELTIAN}

\section{Lokasi Pengambilan Material}

Terak Baja yang digunakan berasal dari PT. Barawaja, Batok Kelapa yang digunakan berasal dari pasar pagi Rantepao Kab. Toraja Utara, Agregat Halus dan Agregat Kasar (Batu Pecah) yang digunakan berasal dari sungai Bili-bili Kab. Gowa.

\section{Pemeriksaan Karakteristik Material}


Dalam penelitian ini, agregat yang digunakan untuk campuran beton mutu tinggi harus diperiksa karakteristiknya sebelum digunakan sebagai benda uji untuk menjamin kualitas mutunya.

Tabel 1. Spesifikasi Karakteristik Agregat Kasar

\begin{tabular}{cccc}
\hline No. & Karakteristik Agregat Kasar & Interval Batas & Pedoman \\
\hline 1 & Kadar Lumpur, \% & $0,2-1,0$ & SNI 03-4142-1996 \\
2 & Kadar Air, \% & $0,5-2,0$ & SNI 03-1971-2011 \\
3 & Berat volume padat, $\mathrm{kg} / \mathrm{ltr}$ & $1,40-1,90$ & SNI 03-4804-1998 \\
4 & Berat volume gembur, kg/ltr & $1,40-1,90$ & SNI 03-4804-1998 \\
5 & Penyerapan, $\%$ & $0,20-2,00$ & SNI 1969-2008 \\
6 & Berat jenis SSD & $1,60-3,20$ & SNI 1969-2008 \\
\hline
\end{tabular}

Tabel 2. Spesifikasi Karakteristik Agregat Halus

\begin{tabular}{cccc}
\hline No. & Karakteristik Agregat Halus & Interval Batas & Pedoman \\
\hline 1 & Kadar lumpur, $\%$ & $0,2-6$ & SNI 03-4142:1996 \\
2 & Kadar organik, warna & $<$ No.3 & 2816:2014 \\
3 & Kadar air, $\%$ & $3-5$ & SNI 03-1971:2011 \\
4 & Berat volume padat, kg/ltr & $1,40-1,90$ & SNI 03-4804:1998 \\
5 & Berat volume gembur, kg/ltr & $0,20-2,00$ & SNI 03-4804:1998 \\
6 & Penyerapan, $\%$ & $0,20-2,00$ & SNI 1970:2008 \\
7 & Berat jenis (SSD) & $1,6-3,2$ & SNI 1970:2008 \\
8 & Modulus kehalusan & $2,20-3,10$ & SNI 03-1968:1990 \\
\hline
\end{tabular}

\section{Desain dan Jumlah Benda Uji}

a. Untuk pengujian kuat tekan, pengujian kuat tarik belah, dan pengujian modulus elastisitas beton benda uji yang digunakan berupa silinder berdiameter $15 \mathrm{~cm}$ dan tinggi $30 \mathrm{~cm}$. Untuk pengujian kuat lentur benda uji yang digunakan berupa balok dengan ukuran $60 \mathrm{~cm}$ x $15 \mathrm{~cm}$ x $15 \mathrm{~cm}$.

b. Pada beton dengan agregat terak baja dan batok kelapa sebanyak 9 silinder untuk pengujian kuat tekan, 3 silinder untuk pengujian kuat tarik belah, 3 balok untuk pengujian kuat lentur, dan 3 silinder untuk modulus elastisitas.

c. Beton pembanding dengan agregat batu pecah sebanyak 9 silinder untuk pengujian kuat tekan, 3 silinder untuk pengujian kuat tarik belah, 3 balok untuk pengujian kuat lentur, dan 3 silinder untuk modulus elastisitas.

d. Jumlah total sampel adalah 36 sampel.

\section{HASIL DAN PEMBAHASAN}

\section{Hasil Pemeriksaan Karakteristik Material}

Tabel 3. Hasil Pemeriksaan Agregat Halus

\begin{tabular}{ccccc}
\hline No. & Karakteristik & Hasil & Interval SNI & Keterangan \\
\hline 1. & Kadar Air $(\%)$ & 3,8 & $3,00-5,00$ & Memenuhi \\
2. & Kadar Organik & No. 1 & $<$ No.3 & Memenuhi
\end{tabular}


Volume 3 Issue 3, September 2021

\begin{tabular}{lcccc} 
3. & Kadar Lumpur $(\%)$ & 2,397 & $0,20-6,00$ & Memenuhi \\
4. & Berat Jenis SSD & 2,507 & $1,60-3,20$ & Memenuhi \\
5. & Absorpsi (Penyerapan) $(\%)$ & 0,910 & $0,20-2,00$ & Memenuhi \\
6. & Berat Volume Padat $\left(\mathrm{kg} / \mathrm{m}^{3}\right)$ & 1670 & $1400-1900$ & Memenuhi \\
7. & Berat Volume Gembur $\left(\mathrm{kg} / \mathrm{m}^{3}\right.$ & 1576,667 & $1400-1900$ & Memenuhi \\
8. & Modulus Kehalusan & 2,623 & $2,20-3,10$ & Memenuhi \\
\hline
\end{tabular}

Tabel 4. Hasil Pemeriksaan Agregat Kasar (Batu Pecah)

\begin{tabular}{ccccc}
\hline No. & Karakteristik & Hasil & Interval SNI & Keterangan \\
\hline 1. & Kadar Air $(\%)$ & 0,705 & $3,00-5,00$ & Memenuhi \\
2. & Kadar Lumpur $(\%)$ & 0,46 & $0,20-6,00$ & Memenuhi \\
3. & Berat Jenis SSD & 2,640 & $1,60-3,20$ & Memenuhi \\
4. & Absorpsi (Penyerapan) $(\%)$ & 1,812 & $0,20-2,00$ & Memenuhi \\
5. & Berat Volume Padat $\left(\mathrm{kg} / \mathrm{m}^{3}\right)$ & 1568,572 & $1400-1900$ & Memenuhi \\
6. & Berat Volume Gembur $\left(\mathrm{kg} / \mathrm{m}^{3}\right)$ & 1486,071 & $1400-1900$ & Memenuhi \\
7. & Modulus Kehalusan & 3,084 & $2,20-3,10$ & Memenuhi \\
\hline
\end{tabular}

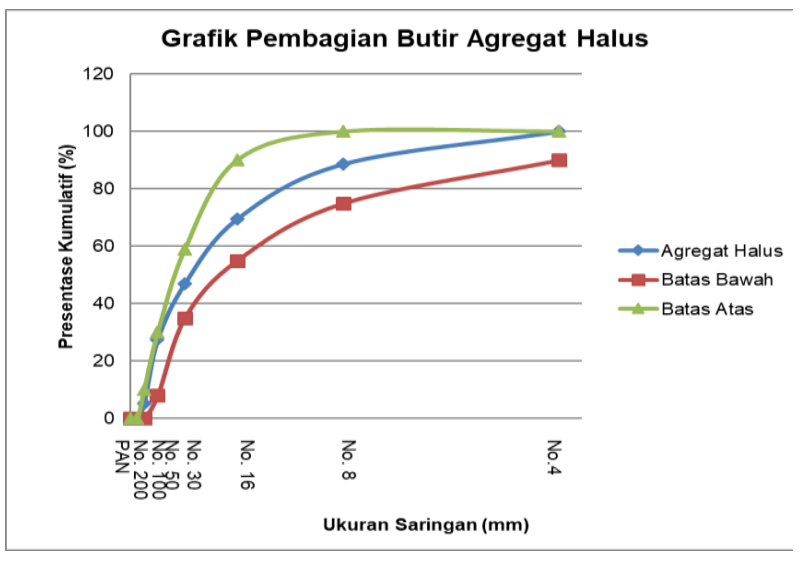

Gambar 1. Grafik Pembagian Butir Agregat Halus

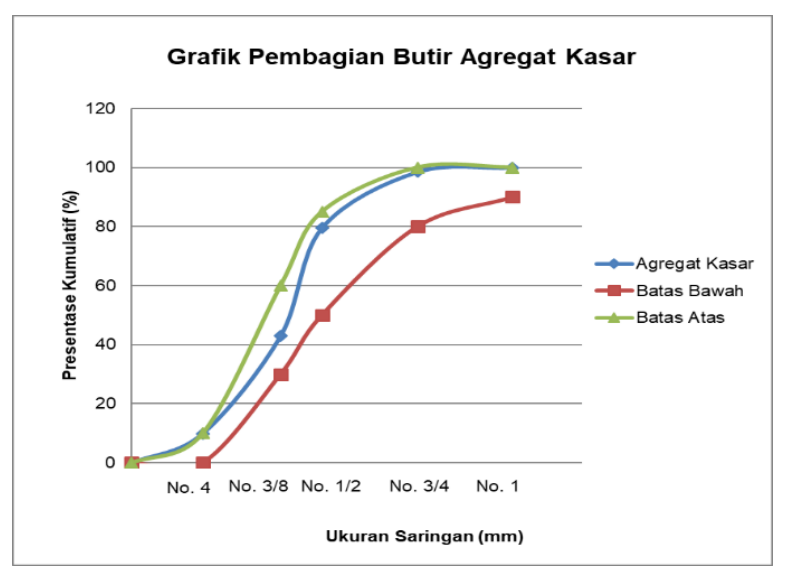

Gambar 2. Grafik Pembagian Butir Agregat Kasar

Tabel 5. Hasil Pengujian Karakteristik Agregat Kasar (Terak Baja)

\begin{tabular}{ccc}
\hline No. & Karakteristik & Hasil \\
\hline 1. & Kadar lumpur, $\%$ & 0,847 \\
2. & Kadar air, $\%$ & 0,685 \\
3. & Berat volume padat, $\mathrm{kg} / \mathrm{m}^{3}$ & 1854 \\
4. & Berat volume gembur, $\mathrm{kg} / \mathrm{m}^{3}$ & 1801 \\
5. & Penyerapan, $\%$ & 1,318 \\
6. & Berat jenis (SSD) & 3,141 \\
\hline
\end{tabular}

Tabel 6. Hasil Pengujian Karakteristik Agregat Kasar (Batok Kelapa)

\begin{tabular}{ccc}
\hline No. & Karakteristik & Hasil \\
\hline 1. & Kadar air, $\%$ & 10,870 \\
2. & Berat volume padat, $\mathrm{kg} / \mathrm{m}^{3}$ & 529,64 \\
3. & Berat volume gembur, $\mathrm{kg} / \mathrm{m}^{3}$ & 461,79
\end{tabular}




\begin{tabular}{lcc} 
4. & Penyerapan, $\%$ & 21,536 \\
5. & Berat jenis (SSD) & 1,298 \\
\hline
\end{tabular}

\section{Mix Design}

Penetitian ini direncanakan dengan mutu f'c $45 \mathrm{MPa}$ dengan metode ACI (American Concrete Institute).

Tabel 7. Komposisi Kebutuhan Bahan Campuran Beton Untuk Beton yang Menggunakan Agregat Kasar (Batu Pecah $100 \%$ )

\begin{tabular}{cc}
\hline Material & Berat $(\mathrm{kg})$ \\
\hline Agregat Kasar & $1078,707 \mathrm{~kg} / \mathrm{m}^{3}$ \\
Agregat Halus & $576,61 \mathrm{~kg} / \mathrm{m}^{3}$ \\
Semen & $482,5 \mathrm{~kg} / \mathrm{m}^{3}$ \\
Air & $193 \mathrm{~kg} / \mathrm{m}^{3}$ \\
\hline
\end{tabular}

Tabel 8. Komposisi Kebutuhan Bahan Campuram Beton Untuk Beton yang Menggunakan Agregat Kasar (Batu Pecah 50\%, Terak Baja 30\%, Batok Kelapa 20\%)

\begin{tabular}{cc}
\hline Material & Berat $(\mathrm{kg})$ \\
\hline Agregat Kasar (Batu Pecah 50\%) & $539,354 \mathrm{~kg} / \mathrm{m}^{3}$ \\
Terak Baja 30\% & $323,612 \mathrm{~kg} / \mathrm{m}^{3}$ \\
Batok Kelapa 20\% & $215,741 \mathrm{~kg} / \mathrm{m}^{3}$ \\
Agregat Halus & $576,61 \mathrm{~kg} / \mathrm{m}^{3}$ \\
Semen & $482,5 \mathrm{~kg} / \mathrm{m}^{3}$ \\
Air & $193 \mathrm{~kg} / \mathrm{m}^{3}$ \\
\hline
\end{tabular}

\section{Hasil Pengujian Kuat Tekan Beton}

Pengujian kuat tekan beton memiliki tujuan untuk mengetahui kekuatan pada beton dalam menerima beban tekan dalam satuan $\mathrm{kN}$.

Tabel 9. Kuat Tekan Beton dengan Agregat Kasar (Batu Pecah 100\%)

\begin{tabular}{ccccccc}
\hline $\begin{array}{c}\text { Agregat } \\
\text { Kasar }\end{array}$ & $\begin{array}{c}\text { Umur } \\
\text { (Hari) }\end{array}$ & $\begin{array}{c}\text { Beban } \\
\text { Maksimum } \\
(\mathrm{kN})\end{array}$ & $\begin{array}{c}\text { Kuat Tekan } \\
\text { Beton Aktual } \\
(\mathrm{MPa})\end{array}$ & $\begin{array}{c}\text { Kuat Tekan } \\
\text { Beton Aktual } \\
\text { Rata-rata (MPa) }\end{array}$ & $\begin{array}{c}\text { Kuat Tekan 28 } \\
\text { Hari (MPa) }\end{array}$ & $\begin{array}{c}\text { Kuat Tekan } \\
\text { Konversi 28 Hari } \\
\text { Rata-rata (MPa) }\end{array}$ \\
\hline & \multirow{2}{*}{5} & 530 & 29,992 & & 46,141 & \\
& & 525 & 29,709 & 30,180 & 45,706 & 46,432 \\
Batu Pecah & \multirow{2}{*}{21} & 795 & 30,841 & & 47,447 & \\
$100 \%$ & & 775 & 44,988 & & 47,356 & \\
& & 800 & 43,856 & 44,705 & 46,164 & 47,058 \\
& \multirow{2}{*}{28} & 825 & 46,685 & & 47,653 & \\
& & 835 & 47,251 & 47,346 & 46,685 & \\
& & 850 & 48,100 & & 47,251 & 47,346 \\
\hline
\end{tabular}

Tabel 10. Kuat Tekan Beton dengan Agregat Kasar (Batu Pecah 50\%, Terak Baja 30\%, Batok Kelapa 20\%)

\begin{tabular}{ccccccc}
\hline $\begin{array}{c}\text { Agregat } \\
\text { Kasar }\end{array}$ & $\begin{array}{c}\text { Umur } \\
(\text { Hari })\end{array}$ & $\begin{array}{c}\text { Beban } \\
\text { Maksimum } \\
(\mathrm{kN})\end{array}$ & $\begin{array}{c}\text { Kuat Tekan } \\
\text { Beton } \\
\text { Aktual } \\
(\mathrm{MPa})\end{array}$ & $\begin{array}{c}\text { Kuat Tekan } \\
\text { Beton Aktual } \\
\text { Rata-rata (MPa) }\end{array}$ & $\begin{array}{c}\text { Kuat Tekan 28 } \\
\text { Hari (MPa) }\end{array}$ & $\begin{array}{c}\text { Kuat Tekan } \\
\text { Konversi 28 Hari } \\
\text { Rata-rata (MPa) }\end{array}$ \\
\hline Batu Pecah & 7 & 520 & 29,426 & 29,332 & 45,271 & 45,126 \\
\hline
\end{tabular}


Volume 3 Issue 3, September 2021

\begin{tabular}{|c|c|c|c|c|c|c|}
\hline \multirow{2}{*}{$\begin{array}{c}50 \%, \\
\text { Terak Baja }\end{array}$} & & 500 & 28,294 & & 43,530 & \\
\hline & & 535 & 30,275 & & 46,577 & \\
\hline \multirow{2}{*}{$\begin{array}{l}30 \%, \\
\text { Batok }\end{array}$} & & 765 & 43,290 & & 45,569 & \\
\hline & 21 & 745 & 42,158 & 43,384 & 44,377 & 45,668 \\
\hline \multirow{4}{*}{$\begin{array}{c}\text { Kelapa } \\
20 \%\end{array}$} & & 790 & 44,705 & & 47,058 & \\
\hline & & 815 & 46,120 & & 46,120 & \\
\hline & 28 & 790 & 44,705 & 45,742 & 44,705 & 45,742 \\
\hline & & 820 & 46,403 & & 46,403 & \\
\hline
\end{tabular}

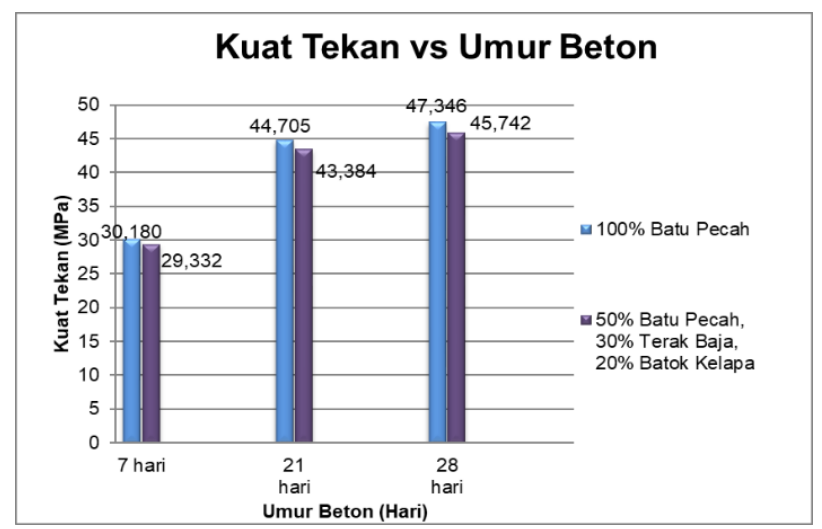

Gambar 3. Diagram hubungan antara Umur Beton dengan Kuat Tekan

Kekuatan tekan beton mengalami kenaikan saat umur beton bertambah. Pada beton dengan agregat kasar batu pecah 50\%, terak baja 30\%, dan batu pecah 20\% memenuhi kuat tekan rencana beton.

\section{Hasil Pengujian Kuat Tarik Belah Beton}

Prosedur pengujian dilaksanakan berdasarkan (SNI 2491-2014). Pengujian kuat lentur beton dilakukan pada umur 28 hari.

Tabel 11. Kuat Tarik Belah Beton

\begin{tabular}{cccc}
\hline Agregat Kasar & Beban Maksimum $(\mathrm{kN})$ & $\begin{array}{c}\text { Kuat Tarik Belah Aktual } \\
(\mathrm{MPa})\end{array}$ & $\begin{array}{c}\text { Kuat Tarik Belah Aktual Rata- } \\
\text { rata (MPa) }\end{array}$ \\
\hline \multirow{2}{*}{ 100\% batu pecah } & 330 & 4,669 & \\
& 305 & 4,315 & 4,409 \\
50\% batu pecah, 30\% & 300 & 4,244 & \\
terak baja, 20\% batok & 270 & 3,820 & 4,150 \\
kelapa & 285 & 4,032 & \\
\hline
\end{tabular}

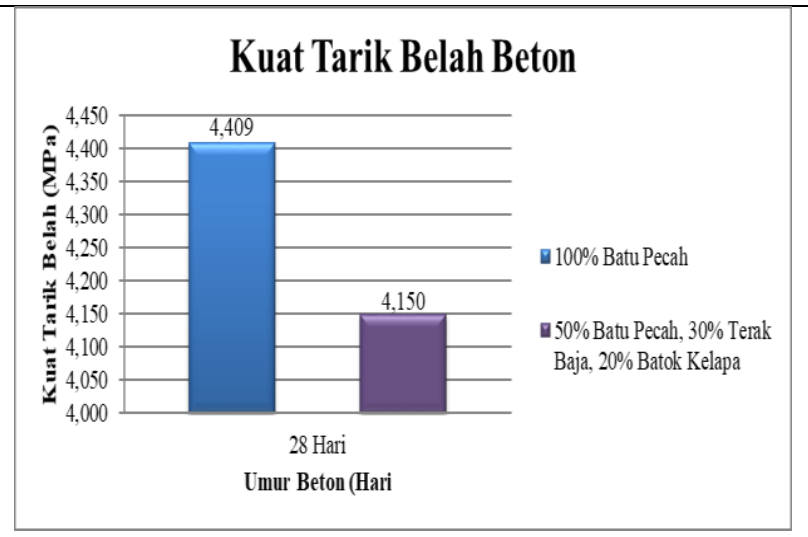


Gambar 4. Hubungan Kuat Tarik Belah Beton dan Umur Beton

hubungan antara beton dengan menggunakan $100 \%$ batu pecah dan beton dengan menggunakan 50\% batu pecah, $30 \%$ terak baja, $20 \%$ batok kelapa pada pengujian kuat tarik belah yaitu nilai kuat tarik belah beton yang menggunakan batu pecah $100 \%$ lebih besar yaitu sebesar 4,409 $\mathrm{MPa}$, dari pada beton yang menggunakan substitusi terak baja dan batok kelapa yaitu sebesar 4,150 MPa.

\section{Hasil Pengujian Kuat Lentur Beton}

Berdasarkan (SNI 4431 - 2011), dilakukan prosedur pengujian dengan benda uji berbentuk balok dengan ukuran 60 x 15 x $15 \mathrm{~cm}$ pada umur 28 hari. Menurut SNI 2847:2013 Pasal 9.5.2.3 modulus keruntuhan beton berkisar antara $11-23 \%$ dari kuat tekan $\left(\mathrm{f}^{\prime} \mathrm{c}\right)$.

Tabel 12. Kuat Lentur Beton

\begin{tabular}{cccc}
\hline Agregat Kasar & Beban Maksimum (Ton) & Kuat Lentur (MPa) & Rata-rata Kuat Lentur (MPa) \\
\hline & 3,6 & 5,441 & \\
100\% Batu Pecah & 3,9 & 5,895 & 5,693 \\
& 3,7 & 5,744 & \\
$50 \%$ Batu Pecah, 30\% & 3,5 & 5,290 & 5,089 \\
terak baja, 20\% batok & 3.4 & 5,139 & \\
kelapa & 3,2 & 4,836 & \\
\hline
\end{tabular}

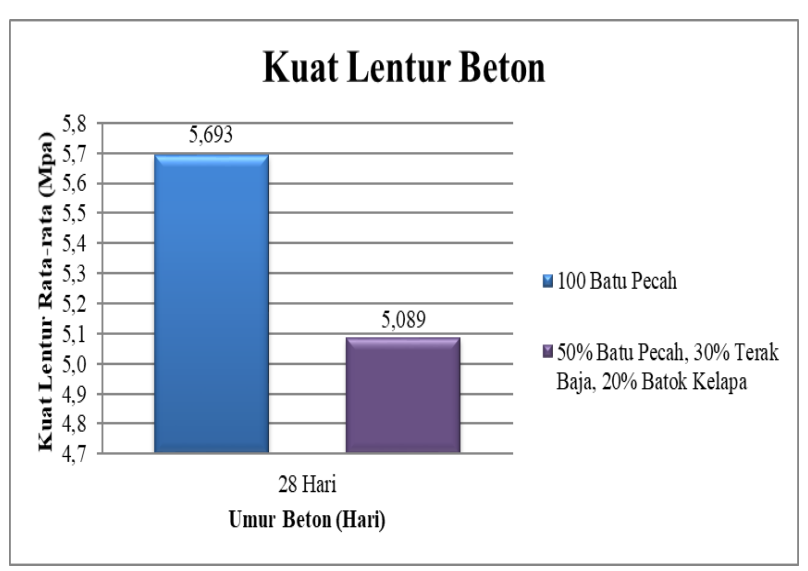

Gambar 5. Hubungan Umur Beton Terhadap Kuat Lentur Beton

Berdasarkan tabel dan gambar menunjukkan hubungan antara beton dengan menggunakan $100 \%$ batu pecah dan beton dengan menggunakan 50\% batu pecah, 30\% terak baja, $20 \%$ batok kelapa pada pengujian kuat lentur beton yaitu nilai kuat lentur beton yang menggunakan batu pecah $100 \%$ lebih besar yaitu sebesar 5,693 MPa, dari pada beton yang menggunakan substitusi terak baja dan batok kelapa yaitu sebesar 5,089 MPa.

\section{Hasil Pengujian Modulus Elastisitas Beton}

Prosedur pengujian dilaksanakan berdasarkan (SNI-4167-1997) ASTM C469. Pengujian modulus elastisitas beton dilakukan pada umur 28 hari. Pada pengujian ini menggunakan adalah silinder beton yang berdiameter $150 \mathrm{~mm}$. dan tinggi $300 \mathrm{~mm}$.

Tabel 13. Modulus Elastisitas Untuk Beton Yang Menggunakan Batu Pecah 100\%

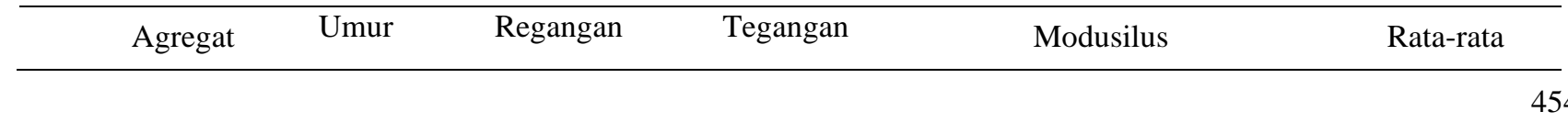




\begin{tabular}{|c|c|c|c|c|c|}
\hline Kasar & & & & Elastisitas (MPa) & Modulus \\
\hline \multirow{3}{*}{$\begin{array}{c}\text { Batu } \\
\text { Pecah } 100 \%\end{array}$} & \multirow{3}{*}{$\begin{array}{r}28 \\
\text { Hari }\end{array}$} & 0,00078 & 18,674 & 23949,030 & \multirow{3}{*}{24845,35} \\
\hline & & 0,00077 & 18,901 & 24461,326 & \\
\hline & & 0,00073 & 19,240 & 26125,697 & \\
\hline
\end{tabular}

Tabel 14. Modulus Elastisitas Untuk Beton Yang Menggunakan Batu Pecah 50\%, Terak Baja 30\%, Batok Kelapa 20\%

\begin{tabular}{cccccc}
\hline $\begin{array}{c}\text { Agregat } \\
\text { Kasar }\end{array}$ & Umur & Regangan & Tegangan & $\begin{array}{c}\text { Modusilus } \\
\text { Elastisitas (MPa) }\end{array}$ & $\begin{array}{c}\text { Rata-rata } \\
\text { Modulus } \\
\text { Elastisitas }\end{array}$ \\
\hline $\begin{array}{c}\text { Batu } \\
\text { Pecah }\end{array}$ & & 0,00090 & 18,448 & 20406,162 & \\
$50 \%$, & 0,00091 & 17,882 & 19364,011 & \\
Terak & 28 & & & & 20674,005 \\
$\begin{array}{c}\text { Baja 30\%, } \\
\text { Batok }\end{array}$ & Hari & & & 22251,842 & \\
Kelapa & & 0,00083 & 16,561 & & \\
20\% & & & &
\end{tabular}

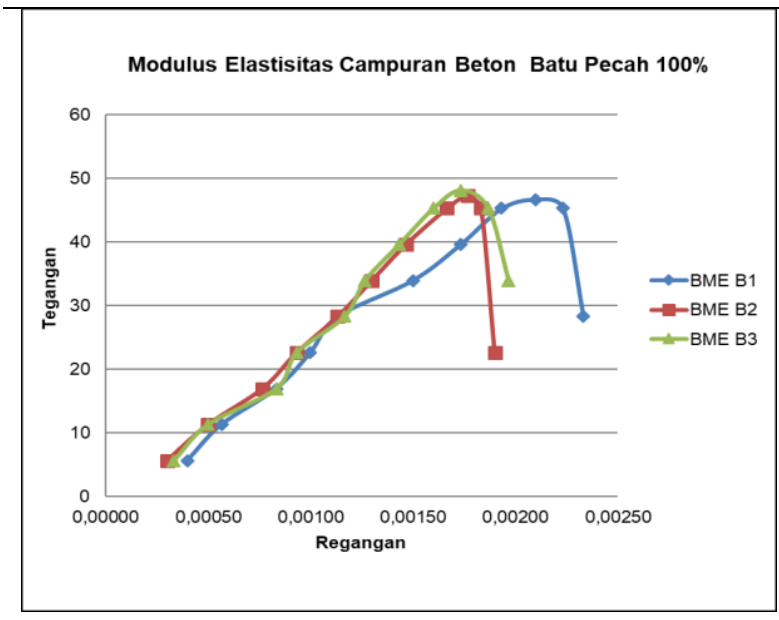

Gambar 6. Hasil Pengujian Modulus Elastisitas Untuk Beton Yang Menggunakan Batu Pecah $100 \%$

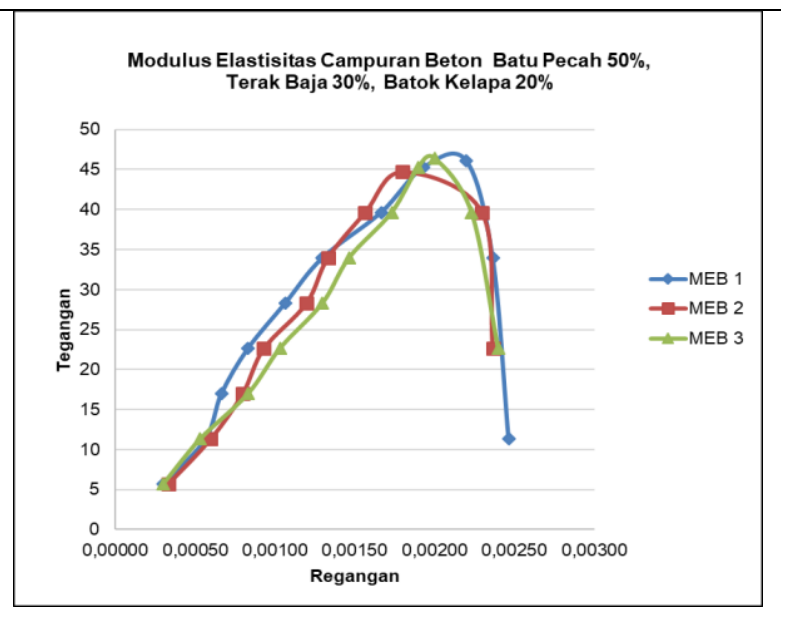

Gambar 7. Hasil Pengujian Modulus Elastisitas Untuk Beton Yang Menggunakan Batu Pecah 50\%, Terak Baja 30\%, Batok Kelapa $20 \%$

Berdasarkan tabel menunjukkan hubungan antara beton dengan menggunakan $100 \%$ batu pecah dan beton dengan menggunakan $50 \%$ batu pecah, $30 \%$ terak baja, $20 \%$ batok kelapa pada pengujian kuat lentur beton yaitu nilai modulus elastisitas beton yang menggunakan batu pecah $100 \%$ lebih besar yaitu sebesar 24845,351 MPa, dari pada beton yang menggunakan substitusi terak baja dan batok kelapa yaitu sebesar 20674,005 MPa.

\section{KESIMPULAN}

Terak baja dan batok kelapa sebagai bahan substitusi agregat kasar pada campuran beton mutu tinggi dapat mempengaruhi beton. Dari hasil pengujian nilai kuat tekan beton pada beton yang menggunakan 
substitusi terak baja dan batok kelapa lebih kecil dari pada beton yang menggunakan batu pecah $100 \%$. Tetapi nilai kuat tekan pada beton yang menggunakan substitusi terak baja dan batok kelapa masih memenuhi kuat tekan rencana yaitu $45 \mathrm{MPa}$.

Perbandingan kuat tekan beton yang menggunakan batu pecah $100 \%$ mengalami kenaikan sebesar $5,213 \%$ dari kuat tekan rencana dan beton yang menggunakan 50\% batu pecah, $30 \%$ terak baja, $20 \%$ batok kelapa mengalami kenaikan sebesar $1,650 \%$ dari kuat tekan rencana. Diperoleh pada beton yang menggunakan batu pecah $100 \%$ nilai kuat tarik belah $9,312 \%$ dari kuat tekan dan pada beton yang menggunakan batu pecah $50 \%$, terak baja $30 \%$, batok kelapa $20 \%$ nilai kuat tarik belah $9,073 \%$. Pada beton yang menggunakan batu pecah $100 \%$ nilai kuat lentur yang di peroleh $0,827 \sqrt{ }($ "f'c" ) dari kuat tekan dan pada beton yang menggunakan batu pecah $50 \%$, terak baja $30 \%$, batok kelapa $20 \%$ nilai kuat lentur yang diperoleh $0,752 \sqrt{ }($ "f'c" ) dari kuat tekan. Modulus elastisitas yang di peroleh pada beton yang menggunakan agregat batu pecah $100 \%$ pada umur 28 hari yaitu sebesar 24845,351 MPa dan untuk beton yang menggunakan agregat batu pecah 50\%, terak baja $30 \%$, batok kelapa $20 \%$ yaitu sebesar 20674,005 MPa.

\section{DAFTAR PUSTAKA}

[1] A. D. Anggara, A. Rahmawati, dan A. Nurhidayati, "Studi Eksperimen Penggantian Agregat Kasar dengan Terak Baja Terhadap Kuat Tekan Beton Normal," IJCEE, vol. 3, no.2, hlm.2-12, 2017.

[2] A. Gunarto, A. I. Candra, K. C. Budi, Sumargono, dan Sudjati, "Pengaruh Limbah Terak Baja Sebagai Agregat Halus, Terhadap Kuat Tekan Beton, "SPIRIT PRO PATRIA, vol. 6, no.2, hlm. 102-111, 2020.

[3] F. Akbar, A. Ariyanto, dan B. Edison, "Penggunaan Tempurung Kelapa Terhadap Kuat Tekan Beton K100," J. Mahasiswa Teknik UPP, 2013.

[4] A. H. Mahindra dan D. Kartikasari, "Pengaruh Abu Tempurung Kelapa Sebagai Variasi Komposisi Terhadap Kuat Tekan Beton K250,”SPIRIT PRO PATRIA, Vol.7, no.1, hlm.26-32, 2021.

[5] S. Silaen, "Pengaruh Penggunaan Terak Baja Sebagai Bahan Pengganti Sebagian Semen Terhadap Kuat Tekan Beton Mutu Tinggi," J. POLIMEDIA, vol.16, no.1, 2013.

[6] T. Anggraeni, W. Septrianto, Supriyo, dan L. Fatmawati, "Studi Analisis Limbah Terak Besi Sebagai Pengganti Sebagian Agregat Halus Pada Pembuatan Paving Block," Wahana TEKNIK SIPIL, vol. 22, no.2, hlm.93-102, 2017.

[7] I. T. Datu, "Karakteristik Mekanis Beton Mutu Tinggi Polypropylene Fiber yang Menggunakan Limbah Slag Baja Sebagai Agregat Kasar," dalam prosiding Seminar Nasional III Teknik Sipil, 2013.

[8] S. Sugiri, "Penggunaan Terak Nikel Sebagai Agregat dan Campuran Semen untuk Beton Mutu Tinggi," Jurnal Infrastruktur dan Lingkungan Binaan, vol.1, no.1, 2005.

[9] M. A. Serang, dan D. Pertiwi, "Pengaruh Pecahan Tempurung Kelapa Sebagai Pengganti Sebagian Agregat Kasar dan Flyash Sebagai Pengisi Pada Campuran Beton Ditinjau dari Kuat Tekan Beton," dalam prosiding Seminar Teknologi Perencanaan, Perancangan, Lingkungan dan Infrastruktur II, 2021.

[10] F. Kurniawan, N. Rasidi, Wisnumurti, dan A. Prawandha, "Pengaruh Penambahan Tempurung Kelapa pada Beton," dalam prosiding Konferensi Nasional Teknik Sipil dan Infrastruktur-I, 2017. 